\title{
Determination of Boron in Natural Water and Products Derived from Grape Using an Automated Flow Injection Analysis System with Piezoelectric Detection
}

\author{
Dosil P. de Jesus, Renata M. Saito and Claudimir L. do Lago* \\ Instituto de Química, Universidade de São Paulo, Av. Prof. Lineu Prestes 748, 05508-900 São Paulo - SP, Brazil
}

\begin{abstract}
Um sistema sensível e seletivo para boro, utilizando um sistema de análise por injeção em fluxo com detecção piezelétrica, é apresentado. O detector é um cristal piezelétrico de quartzo com eletrodo separado recoberto com filme de poliepicloridrina modificada com N-metil-D-glucamina. A capacidade do filme em reter boro possibilita ampliar a faixa de resposta linear e a sensibilidade, variando o volume de amostra injetada. Neste trabalho, o volume de amostra variou de 0,5 a 5,0 mL. Dentre diversos íons analisados, germanato foi o único interferente. Entretanto, essa interferência pode ser eliminada com a adição de sulfeto à amostra. $\mathrm{O}$ método se mostrou eficiente na determinação de boro em amostras de água natural (de 1,71 a $309 \mu \mathrm{g} \mathrm{L}^{-1}$ ) e produtos derivados da uva (de 2,06 a 6,21 mg $\left.\mathrm{L}^{-1}\right)$. Um pré-tratamento com peróxido de hidrogênio em meio básico foi necessário devido à grande quantidade de carboidratos presentes no suco de uva.
\end{abstract}

An automated flow injection analysis system with piezoelectric detection is proposed as a sensitive and selective method for boron. The detector is an electrode-separated piezoelectric quartz crystal coated with N-methyl-D-glucamine-modified poly(epichlorohydrin). The film ability to retain boron allows the adjustment of the linear dynamic range and the sensitivity by varying the injected sample volume. In the present work, the sample volumes were varied from 0.5 to $5.0 \mathrm{~mL}$. Among several ionic species, germanate is the only one that can interfere in the method. Nevertheless, it can be eliminated by addition of sulfide to the sample. The method was successfully applied to the determination of boron concentration in samples of natural water (from 1.71 to $309 \mu \mathrm{g} \mathrm{L}^{-1}$ ) and products derived from grape juice (from 2.06 to $6.21 \mathrm{mg} \mathrm{L}^{-1}$ ). A pretreatment with hydrogen peroxide in alkaline medium was required due to the great amount of sugars in the grape products.

Keywords: boron, flow injection analysis, piezoelectric quartz crystal, grape juice, wine, natural water

\section{Introduction}

The determination of boron at low and high concentrations is very important in the foods, electronic components, glass, steel, fertilizers, detergents, and health care products industries. ${ }^{1,2}$ Boron concentration can be used as an indicator of industrial and domestic pollution in groundwaters. ${ }^{3}$ In the agriculture the monitoring of boron content in soil and water irrigation is particularly relevant since this element is an essential nutrient for plant growth. ${ }^{4}$ On the other hand, boron excess can be fatal. The determination of boron in natural water and foods is also interesting, because some studies ${ }^{5}$ have suggested that it plays an important role in the metabolism of minerals in animals and humans.

*e-mail: claudemi@iq.usp.br
It is clear, then, that sensitive, selective, and accurate methods for boron determination are necessary. Sah and Brown $^{6,7}$ reviewed several methods for determination of boron that have been reported in the literature. Methods based on spectrophotometry and fluorimetry are prone to the interference of several species. For potentiometric determinations, boron needs to be converted into $\mathrm{BF}_{4}-$ before detection; moreover this method is strongly affected by sample matrix. Mass spectrometry methods are the most sensitive, selective, and accurate for boron determination. ${ }^{8-}$ ${ }^{10}$ Nevertheless these methods are very expensive.

Most flow injection methods for boron reported in the literature ${ }^{11-15}$ are based on spectrophotometric detection that employs chromogenic reagents such as chromotropic acid, azomethine- $\mathrm{H}$, and curcumine.

In a previous work, ${ }^{16}$ we introduced a new sensor for boron based on an electrode-separated piezoelectric quartz 
crystal (PQC). It was shown that a N-methyl-D-glucaminemodified poly(epichlorohydrin) film retains boron and determines the frequency shift of an electronic oscillator. This sensor exhibited high sensitivity and selectivity for synthetic boron solutions. In the present paper, an automated flow injection analysis (FIA) system using the PQC sensor as an alternative method for boron determination is proposed. The method was evaluated for analysis of natural waters and products derived from grape. These samples were chosen because they represent two different challenges. In the first case, low levels of boron are expected. In the second case, high content of hydrocarbons causes the formation of stable complexes, which prevent the retention of boron on the PQC.

\section{Experimental}

\section{PQC boron sensor}

This sensor has been described in detail elsewhere. ${ }^{16}$ Briefly, a $5 \mathrm{MHz}$ AT-cut PQC (International Crystal Manufacturing, Oklahoma, OK) is placed in a flow cell with an electrode-separated configuration and the oscillation frequency is monitored. The improvement of sensitivity and selectivity for boron is achieved by coating the PQC with a thin film $(\sim 0.5 \mu \mathrm{m})$ of poly(epichlorohydrin) modified with $\mathrm{N}$-methyl-D-glucamine.

\section{Automated FIA system}

Figure 1 shows the schematic diagram of the automated FIA system used for boron determination. The parts enclosed in the dashed polygon (Figure 1) are kept in a Plexiglas case under controlled temperature conditions $\left(\sim 30{ }^{\circ} \mathrm{C}\right)$. A peristaltic pump MS Reglo (Ismatec, Glattbrugg, Switzerland) was used for propelling simultaneously, at the same flow rate, the buffer solution and another one (carrier, cleaning, or sample) selected by switching the solenoid valves (NResearch, West Caldwell, $\mathrm{NJ})$. The pumped solutions are mixed into coil 4 made of a poly(tetrafluorethylene) tube $(60 \mathrm{~cm}$ length and $0.8 \mathrm{~mm}$ i.d.). This mixture results in a constant $\mathrm{pH}$ and temperature solution that reaches the detection cell (PQC boron sensor). The temperature control of the solutions, except the sample, is achieved by passing them through coils 1,2 , and 3 , which consist of poly(ethylene) tubes ( $2.5 \mathrm{~m}$ length and $0.9 \mathrm{~mm}$ i.d.) rolled on copper tubes $(70 \mathrm{~mm}$ length and $15 \mathrm{~mm}$ o.d.) that allow a better heat exchange. This temperature control is very important in order for the boron sensor to provide a stable baseline signal. An interface board AT-MIO-16XE-50 (National Instruments, Austin, TX) and a software implemented using Delphi 5.0 (Borland, Scotts Valley, CA) allow a microcomputer to control the peristaltic pump speed, the switching of the solenoid valves and the monitoring of temperature and frequency oscillation. The FIA system can be programmed to do injections of sample and cleaning solutions at flow rate and duration established in advance.

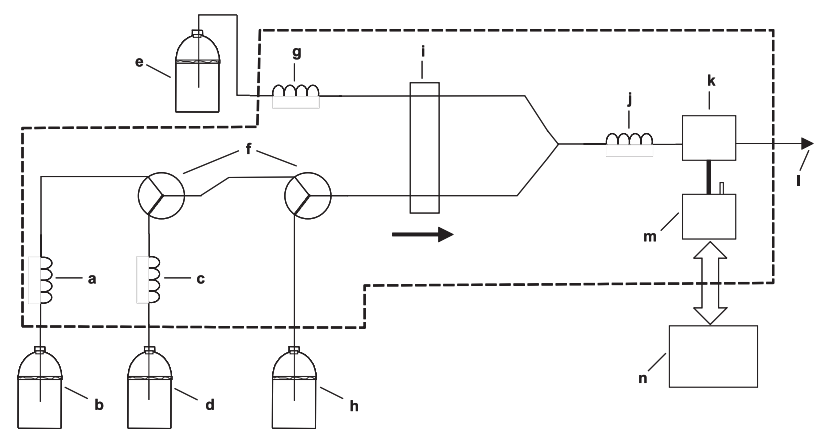

Figure 1. Schematic diagram of the automated FIA system: (a) coil 1; (b) carrier solution; (c) coil 2; (d) cleaning solution; (e) buffer solution; (f) solenoid valves; (g) coil 3; (h) sample solution; (i) peristaltic pump; (j) coil 4; (k) detection cell; (1) waste; (m) oscillator circuit; (n) microcomputer with interface board ATMIO-16XE-50.

Samples, solutions, and reagents

All reagents were of analytical grade and deionized water Nanopure (Barnstead Thermolyne, Dubuque, IA) was used to prepare the solutions that were stored in polyethylene bottles.

The buffer solution was prepared by dissolving $10.6 \mathrm{~g}$ of $\mathrm{NH}_{4} \mathrm{Cl}$ and $16.8 \mathrm{~g}$ of EDTA, disodium salt (Celm, Barueri, Brazil), the $\mathrm{pH}$ was adjusted to 9.0 using concentrated ammonia (Merck, Rio de Janeiro, Brazil) and the volume was completed to $2.5 \mathrm{~L}$ with deionized water. The presence of EDTA prevents the interference of metal ions.

Although the composition of the carrier solution does not need to match the composition of the sample, the similarity among them makes the register easier to interpret, because no significant change of conductivity or viscosity occurs. However, there is no decrease of performance if this similarity is not attained. Thus, for the preconcentrated water samples, the carrier solution was a $0.25 \mathrm{~mol} \mathrm{~L}^{-1} \mathrm{NaCl}$, and for non-preconcentrated samples, only deionized water was used. For the NIST water sample, a $0.1 \mathrm{~mol} \mathrm{~L}^{-1} \mathrm{NaNO}_{3}$ solution was used. A $0.5 \mathrm{~mol} \mathrm{~L}^{-1}$ sodium acetate solution was used as carrier for the products derived from grape.

Cleaning solution was prepared by dissolving $18.2 \mathrm{~g}$ of mannitol (Carlo Erba, Milan, Italy) in $100 \mathrm{~mL}$ of deionized water. 
Standard solutions of boron (as borate) were prepared by diluting a $0.1 \mathrm{~mol} \mathrm{~L}^{-1}$ stock boron solution, obtained by dissolving $0.6183 \mathrm{~g}$ of boric acid in $100 \mathrm{~mL}$ of deionized water. Germanium solutions used in the interference tests were prepared by diluting a $0.05 \mathrm{~mol} \mathrm{~L}^{-1}$ stock solution, obtained by dissolving $0.261 \mathrm{~g}$ of $\mathrm{GeO}_{2}$ in $50 \mathrm{~mL}$ of $0.1 \mathrm{~mol} \mathrm{~L}^{-1} \mathrm{NaOH}$ solution. All dilutions were performed using the appropriated carrier solutions in order to prevent significant changes of $\mathrm{pH}$ and conductivity.

Natural waters, grape juice, wine, and aceto balsamic vinegar samples were acquired from local supermarkets. Certified water sample SRN 1640 was purchased from NIST (Gaithersburg, MD).

\section{Sample preparation}

Most evaluated natural water contained low boron concentration, thus a preconcentration step was carried out by passing $100 \mathrm{~mL}$ of the sample (flow rate $1 \mathrm{~mL} \mathrm{~min}{ }^{-1}$ ) through a column $(70 \mathrm{~mm}$ length and $5 \mathrm{~mm}$ id) filled with $750 \mathrm{mg}$ of boron-selective ion-exchange resin Amberlite IRA 743 (Aldrich, Milwaukee, WI). The retained boron was eluted from the column using $5 \mathrm{~mL}$ (flow rate $85 \mu \mathrm{L} \mathrm{min}^{-1}$ ) of $0.5 \mathrm{~mol} \mathrm{~L}^{-1} \mathrm{HCl}$. The eluted solution was neutralized by $3 \mathrm{~mol} \mathrm{~L}^{-1} \mathrm{NaOH}$ and the volume was then completed to 10 $\mathrm{mL}$. Therefore, the samples were preconcentrated by a factor of 10 .

For the products derived from grape (juice, wine, and vinegar), a pretreatment was necessary to destroy the carbohydrates present at high concentrations. These polyols form stable complexes with boron and compete with the sensor for the analyte. The pretreatment was carried out by adding $16 \mathrm{~mL}$ of $3 \mathrm{~mol} \mathrm{~L}^{-1} \mathrm{NaOH}$ and $16 \mathrm{~mL}$ of $\mathrm{H}_{2} \mathrm{O}_{2} 30 \%(\mathrm{v} / \mathrm{v})$ in $5 \mathrm{~mL}$ of each sample. The samples were heated $\left(\sim 90^{\circ} \mathrm{C}\right)$ until the volume was reduced to a half in order to eliminate $\mathrm{H}_{2} \mathrm{O}_{2}$ excess. The treated samples were neutralized with glacial acetic acid and the volumes were completed to $50 \mathrm{~mL}$ with deionized water.

For the NIST water sample preconcentration and pretreatment were not necessary. Five $\mathrm{mL}$ of this sample was neutralized with $1 \mathrm{~mol} \mathrm{~L}^{-1} \mathrm{NaOH}$ and the volume was completed to $25 \mathrm{~mL}$ with deionized water.

\section{Analytical procedure}

Analytical curves were obtained with standard boron solutions at appropriated concentrations and used for the boron quantification. The flow rate of $1 \mathrm{~mL} \mathrm{~min}^{-1}$ was adopted for the solutions employed in the FIA system. For the water samples an injected volume of $3 \mathrm{~mL}$ was used, except for the NIST sample, from which $2 \mathrm{~mL}$ were used.
The injected volume of the prepared sample of products derived from grape was $0.5 \mathrm{~mL}$. All sample injections were carried out in triplicate, except for the NIST water sample that was injected 5 times.

\section{Results and Discussion}

\section{Characteristics of the PQC boron sensor}

Figure 2 shows the sensor response for triplicate injections of $0.7 \mathrm{~mL}$ of a $250 \mu \mathrm{g} \mathrm{L}^{-1}$ boron solution. Boron retention in the polymeric film on the PQC causes an increase in the frequency oscillation. This positive frequency shift was studied in our previous work ${ }^{16}$ and was attributed to a predominantly nongravimetric mechanism of detection. It is based on an increase in the stiffness of the PQC coating film caused by a complex formation between boron and the N-methyl-D-glucamine groups present in the modified polymer. The original baseline is restored after boron is removed from the film by the injection of $1.0 \mathrm{~mol}$ $\mathrm{L}^{-1}$ mannitol cleaning solution. The negative frequency shift caused by the cleaning solution is mainly due to the higher viscosity of this solution.

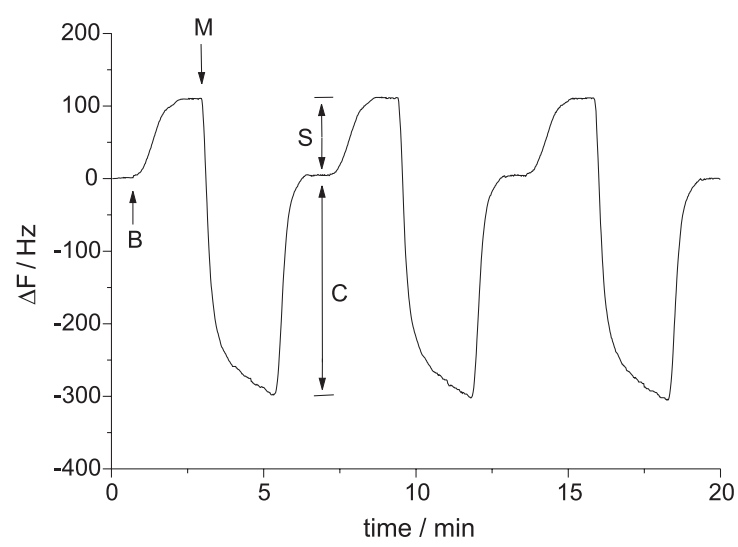

Figure 2. Sensor response for three $0.7 \mathrm{~mL}$ injections of a $250 \mu \mathrm{g} \mathrm{L}^{-1}$ boron solution. Marks $\mathbf{B}$ and $\mathbf{M}$ indicate the insertion moment of the boron and $1.0 \mathrm{~mol} \mathrm{~L}^{-1}$ mannitol cleaning solutions, respectively, into the detection cell. The frequency shifts $\mathbf{S}$ and $\mathbf{C}$ are attributed to boron retention and to the higher viscosity of the mannitol solution, respectively.

The sensor response is linearly proportional to the boron concentration in the injected solution as showed in Figure 3 . Figure 4 shows the response of the sensor as a function of the injected volumes of a $200 \mu \mathrm{g} \mathrm{L}^{-1}$ boron solution. It can be observed the sensor ability to retain boron allows improving the sensitivity of the method by increasing the injected sample volume. For this purpose, the automated FIA system is very convenient, since it provides an easy way of changing the injected sample volume and an 
efficient temperature control that prevents baseline drift. The linear response of the sensor as function of the injected sample volume can be used to obtain analytical curves using only a single boron standard solution. Moreover, this feature allows establishing the linear dynamic range of the method according to the level of boron in the sample.

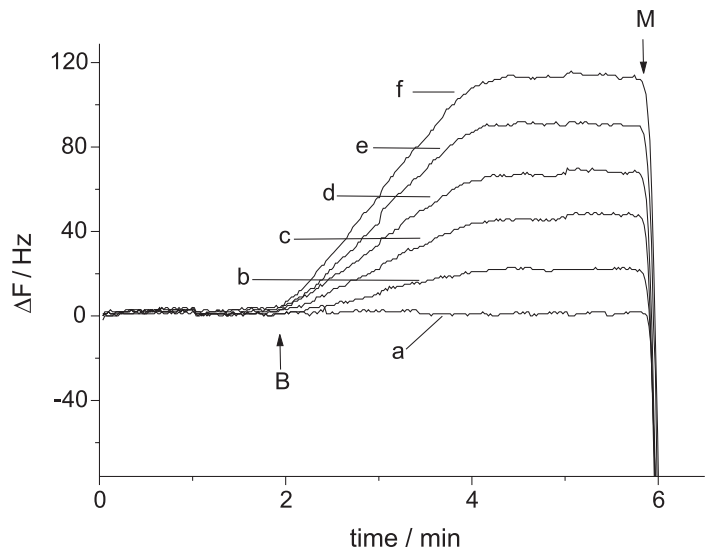

Figure 3. Sensor response for $2 \mathrm{~mL}$ injections of solutions containing different boron concentrations. (a) 0; (b) 20; (c) 40; (d) 60; (e) 80; (f) $100 \mu \mathrm{g} \mathrm{L}^{-1}$. Marks $\mathbf{B}$ and $\mathbf{M}$ indicate the insertion moment of the boron and $1.0 \mathrm{~mol} \mathrm{~L}^{-1}$ mannitol cleaning solutions, respectively, into the cell.

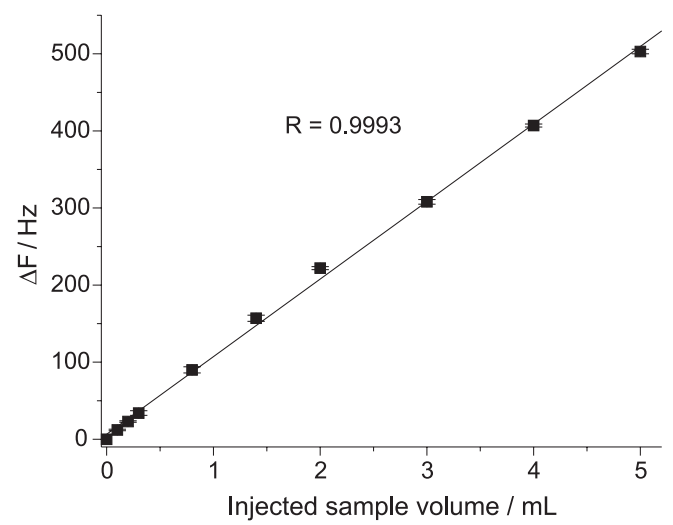

Figure 4. Sensor response as a function of the injected volume of a $200 \mu \mathrm{g} \mathrm{L}^{-1}$ boron solution.

The method allows detecting down to $3 \mathrm{ng}$ of boron. The analysis throughput varies with the injected volumes of sample and cleaning solution. For injections of $0.5 \mathrm{~mL}$ of sample and $2 \mathrm{~mL}$ of cleaning solution, it is possible to carry out 12 analysis/h.

\section{Interferences}

In earlier work, ${ }^{16}$ it was found the PQC boron sensor was not affected by several ions such as $\mathrm{Mg}^{2+}, \mathrm{Ca}^{2+}, \mathrm{Al}^{3+}, \mathrm{Cr}^{3+}$, $\mathrm{Mn}^{2+}, \mathrm{Fe}^{3+}, \mathrm{Co}^{2+}, \mathrm{Ni}^{2+}, \mathrm{Zn}^{2+}, \mathrm{Sn}^{2+}, \mathrm{Pb}^{2+}, \mathrm{HPO}_{4}^{2-}, \mathrm{SiO}_{3}^{2-}, \mathrm{F}^{-}, \mathrm{Cl}^{-}$, $\mathrm{SO}_{4}^{2-}, \mathrm{NO}_{3}^{-}, \mathrm{CH}_{3} \mathrm{COO}^{-}, \mathrm{CO}_{3}^{2-}, \mathrm{VO}_{3}^{-}, \mathrm{MoO}_{4}^{2-}, \mathrm{WO}_{4}^{2-}, \mathrm{Sb}(\mathrm{OH})_{6}^{-}$,
$\mathrm{AsO}_{4}^{3-}, \mathrm{AsO}_{3}{ }^{3-}, \mathrm{SeO}_{3}{ }^{2-}$, and $\mathrm{SeO}_{4}{ }^{2-}$ at concentration of $1 \mathrm{mmol}$ $\mathrm{L}^{-1}$. Only the presence of polyols was troublesome. However, in the present work germanium as $\mathrm{Ge}(\mathrm{OH})_{6}{ }^{2-}$ was found to be a significant interferent. Nevertheless, the addition of sulfide to the sample eliminates completely this interference (as showed in Figure 5). Germanium forms complex with $\mathrm{N}$-dimethyl-D-glucamine similarly to boron, but the previous formation of germanium sulfide prevents its retention by the sensor film.

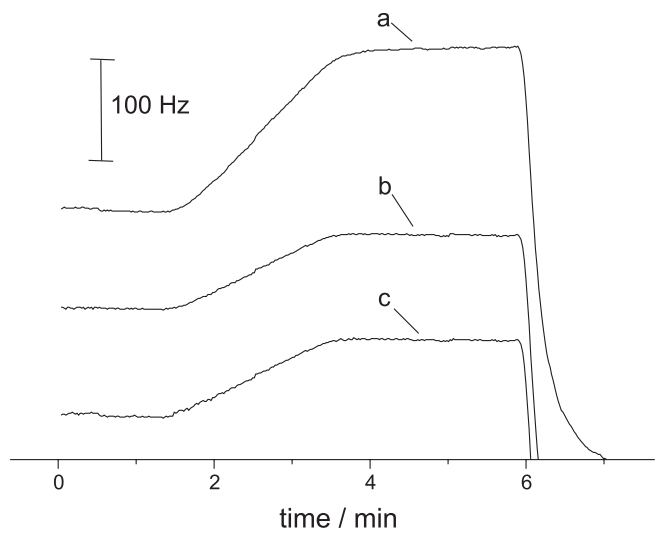

Figure 5. Sensor response for $2 \mathrm{~mL}$ injections of solutions containing (a) $80 \mu \mathrm{g} \mathrm{L}^{-1}$ boron and $720 \mu \mathrm{g} \mathrm{L}^{-1}$ germanium; (b) $80 \mu \mathrm{g} \mathrm{L}^{-1}$ boron, $720 \mu \mathrm{g} \mathrm{L}^{-1}$ germanium, and $200 \mu \mathrm{mol} \mathrm{L} \mathrm{L}^{-1}$ sulfide; (c) $80 \mu \mathrm{g} \mathrm{L}^{-1}$ boron. The curves were shifted to provide a better visualization.

\section{Sample analysis}

Table 1 shows the boron content in the water samples. The boron quantity in samples DW1 and NIST was sufficient to be quantified without preconcentration. The boron concentration found in the certified sample is statistically concordant (t-test at $95 \%$ of confidence) with the value certified by NIST, which indicates that the method has a good accuracy for this matrix.

Table 1. Analysis of water samples

\begin{tabular}{cc}
\hline Sample & Boron concentration $\left(\mu \mathrm{g} \mathrm{L}^{-1}\right)$ \\
\hline DW1 & $45.0 \pm 1.5$ \\
DW2 & $13.2 \pm 1.1$ \\
DW3 & $3.25 \pm 0.08$ \\
DW4 & $1.71 \pm 0.16$ \\
DW5 & $2.32 \pm 0.08$ \\
DW6 & $2.04 \pm 0.03$ \\
SRN 1640 $(301.1 \pm 6.1)^{\mathrm{a}}$ & $309 \pm 6$ \\
\hline
\end{tabular}

aboron concentration $\left(\mu \mathrm{g} \mathrm{L}^{-1}\right)$ certified by NIST.

In all water samples, ammonium sulfide was added ( $1 \mathrm{mmol} \mathrm{L}^{-1}$ ) to check if germanium interference was present. However, no change in the frequency shift was found. This was expected because, as described in the literature, ${ }^{17-19}$ the concentration of germanium in natural water is very small $\left(\mathrm{ng} \mathrm{L}^{-1}\right)$. 
Although the analysis of the water samples with low boron content can be done by injecting a large volume, sample preconcentration was preferred, because this procedure allows a higher throughput, since several samples can be prepared simultaneously using various ion exchange (Amberlite IRA-743) columns.

Most of the methods to decompose organic material employ an acidic and oxidant medium, however in this work an alkaline medium was used to avoid boron evaporation from the sample. Volatile boron fluoride, chloride, and esters can be formed in acid medium. Hydrogen peroxide is a suitable oxidant, because heating easily eliminates its excess. Otherwise, a residual amount of oxidant could oxidize the sensor film. Table 2 provides the results of the analysis of the products derived from grape and the recovery of boron added before the pretreatment. Boron was added as boric acid and allowed reach equilibrium with the organic material by at least $2 \mathrm{~h}$. The good recoveries indicate that the analyte is not lost during the treatment and the polyols interference is efficiently eliminated. The maintenance of the sensitivity of the sensor after a great number of analyses indicates that no significant amount of oxidant substance remains after the pretreatment. Again, the presence of germanium was not also observed.

Table 2. Analysis of products derived from grape

\begin{tabular}{lcc}
\hline Sample & $\begin{array}{c}\text { Boron concentration } \\
\left(\mathrm{mg} \mathrm{L}^{-1}\right)\end{array}$ & $\begin{array}{c}\text { Recovery } \\
(\%)\end{array}$ \\
\hline Grape Juice 1 & $2.06 \pm 0.19$ & $98 \pm 2$ \\
Grape Juice 2 & $2.23 \pm 0.11$ & not evaluated \\
Vinegar & $6.2 \pm 0.2$ & $100 \pm 4$ \\
Wine & $5.5 \pm 0.2$ & $101 \pm 6$ \\
\hline
\end{tabular}

a Average of three measurements and the resulting estimated standard deviation; ${ }^{\mathrm{b}}$ Based on a $4 \mathrm{mg} \mathrm{L}^{-1}$ boron spike.

\section{Conclusion}

The method for boron determination involving an automated FIA system with piezoelectric detection has proved to be very sensitive, selective, and accurate. The boron retention character of the $\mathrm{PQC}$ sensor allows defining the linear dynamic range and the sensitivity of the method by varying the injected sample volume. Such feature guarantees good performance of the method for boron determination at low and high concentrations. The results show that the proposed method can be successfully applied to the determination of boron in natural water without pretreatment. The mineralization is necessary for samples with high concentration of polyols. The proposed sample treatment based on oxidation with hydrogen peroxide in alkaline medium is suitable in these cases, because there is no evidence of interferences and oxidant residue.

\section{Acknowledgements}

This work was supported by the Fundação de Amparo à Pesquisa do Estado de São Paulo (FAPESP). Authors wish to thank Conselho Nacional de Desenvolvimento Científico e Tecnológico CNPq and FAPESP for the fellowships, Dr. L. Angnes and E. M. Richter for providing, respectively, the $\mathrm{GeO}_{2}$ and the NIST sample and A. J. Richter for the English revision.

\section{Rererences}

1. Mark, H.F.; McKetta, J.J.; Othmer, D.F.; Encyclopedia of Chemical Technology, $2^{\text {nd }}$ ed., John Wiley \& Sons: New York, 1968; vol. 3, pp. 602-737 and vol. 4, pp. 86-87.

2. Hunt, C.D.; Shuler, T.R.; Mullen, L.M.; J. Amer. Diet. Assoc. 1991, 91, 558

3. Vengosh, A.; Heumann, K.G.; Juraske, S.; Kasher, R.; Envirom. Sci. Technol. 1994, 28, 1968.

4. Shorrocks, V.M.; Plant Soil 1997, 193, 121.

5. Naghii, M.R.; Samman, S.; Prog. Food Nutr. Sci. 1993, 17, 331.

6. Sah, R.N.; Brown, P.H.; Microchem. J. 1997, 56, 285.

7. Sah, R.N.; Brown, P.H.; Plant Soil 1997, 193, 15.

8. Gregoire, D.C.; J. Anal. At. Spectrom. 1990, 5, 623.

9. Demuth, N.; Heumann, K.G.; J. Anal. At. Spectrom. 1999, 14, 1449.

10. Moraes, M.C.B.; Brito Neto, J.G.A.; Lago, C.L.; Inter. J. Mass Spectrom. 2000, 198, 121.

11. Sekerka, I.; Lechner, J.F.; Anal. Chim. Acta 1990, 234, 199.

12. Lussier, T.; Gilbert, Hubert, R.; J. Anal. Chem. 1992, 64, 2201.

13. Nogueira, A.R.A.; Brienza, S.M.B.; Zagatto, E.A.G.; Lima, J.L.F.C.; Araújo, A.N.; Anal. Chim. Acta 1993, 276, 121.

14. Pérez, E.L.; Ríos, A.; Valcárcel, M.; Anal. Chem. 1997, 69, 91.

15. Sanchez-Ramos, S.; . Medina-Hernández, M.J; Sagrado, S.; Talanta 1998, 45, 835 .

16. Jesus, D.P.; Neves, C.A.; Lago, C.L.; Anal. Chem. 2002, 74, 3274

17. Aucelio, R.Q.; Rubin, V. N.; Becerra, E.; Smith, B. W.; Winefordner, J. D.; Anal. Chim. Acta 1997, 350, 231.

18. Tao, G.H.; Fang, Z.L.; J. Anal. At. Spectrom. 1993, 8, 577.

19. Brindle, I.D.; Brindle, M.E.; Le, X.C.; Chen, H. W.; J. Anal. At. Spectrom. 1991, 6, 129.

Received: January 22, 2004

Published on the web: August 4, 2004

FAPESP helped in meeting the publication costs of this article. 